\title{
DOI 10.26886/2414-634X.7(43)2020.4
}

UDC: 378.147

INNOVATIVE METHODS FOR MODERNIZATION OF PHYSICAL EDUCATION OF FUTURE MILITARY DOCTORS

\section{O. Moshkovskyy}

https://orcid.org/0000-0002-7813-2818

e-mail: moshkovskyy.o@gmail.com

Deputy Head of Sviatoshynskyi District State Administration, Ukraine, Kyiv

The article is devoted to the importance of quality physical training for future military doctors, whose work, in emergency situations, carries significant physical and emotional stress. The purpose of this publication involves the search for innovative methods to modernize the educational process of physical education. For this purpose the results of scientific researches of the organization of educational and extracurricular process of physical education were analyzed. Based on the scientific literature and in accordance with modern world and national trends, the article proposes to modernize the process of physical education, through a person-centered approach and the inclusion in the educational process of additional sportsoriented activities designed to improve physical skills and harmonize consciousness.

Keywords: physical education, physical fitness, personality-oriented training, yoga, fitness, combat hopak.

заступник голови Святошинської районної в місті Києві державної адміністрації Мошковський О. М. Інноваційні методи для модернізації фрізичного виховання майбутніх військових лікарів, Україна, Київ

Стаття присвячена важливості якісної фрізичної підготовки майбутніх військових лікарів робота яких, в умовах надзвичайних ситуацій, несе в собі значні фрізичні та психоемоційні навантаження. 
Мета даної публікації передбачає пошуки інноваційних методів для модернізації освітнього процесу фрізичного виховання. Саме для цього було проаналізовано результати наукових досліджень організації навчального та позанавчального прочесу фрізичного виховання. На основі наукової літератури та у відповідності сучасним світовим $i$ національним тенденціям, в статmі запропоновано здійснити модернізацію процесу фрізичного виховання, шляхом особистісноорієнтованого підходу та включенням до освітнього процесу додаткових спортивно-орієнтованих занять, які покликані вдосконалювати фрізичні навички та гармонізувати свідомість.

Ключові слова: фрізичне виховання, фрізична підготовленість, військові лікарі, особистісно-орієнтоване тренування, йога, фрітнес, бойовий гопак.

Вступ. Аналіз світової системи медичної та військово-медичної освіти свідчить, що підготовка медичних фрахівців $є$ тривалим, багатоступеневим і безперервним процесом, що потребує значного напруження фрункціональних можливостей організму при засвоєнні відповідних теоретичних знань і практичних навичок [1]. Нестримний розвиток засобів і способів збройної боротьби, особливо за умов гібридної війни на Сході України, коли військовослужбовці стикаються 3 цілим комплексом проблем, таких як колосальне фрізичне та інформаційне навантаження, психоемоційний стрес, докорінно змінив підхід до фрормування обрису сучасного захисника Вітчизни та змусив кожного переглянути свої погляди щодо подальшого розвитку свого здоров'я та фрізичної підготовленості (ФП) [2]. При виконанні бойових завдань саме ФП військовослужбовців сприяє підтриманню здоров'я і підвищенню спротиву впливу небезпечних фракторів. Не випадково в останні роки все частіше йдеться про фрізичну культуру не тільки як про самостійний соціальний феномен, але і як про стійку якість особистості. 
Саме ФП є природним містком, що дозволяє з'єднати моральний і фрізичний розвиток військовослужбовця [3].

Аналіз останніх досліджень і публікацій. Сьогодні чимало українських науковців здійснюють оптимальні пошуки організації навчального та позанавчального процесу фізичного виховання. Так, у наукових працях А. І. Драчука та співавт. [4], А. А. Домашенко та співавт. [5], О. С. Куца та П. С. Данчук [6], Р. Т. Раєвського та В. І. Філінкова [7] наголошується, що теперішня організація фрізичного виховання у закладах вищої освіти є недостатньо ефективною для підвищення рівня здоров'я, ФП та мотивації до систематичних занять фрізичними вправами. Це завдання найбільш гостро стоїть перед вищою школою, яка $є$ базовою ланкою підготовки здорового висококваліфікованого спеціаліста [8].

Т. Круцевич та співавт., досліджуючи причини політики девальвації фрізичної підготовки в системі фрізичного виховання в закладах освіти України стверджують, що сучасна система фрізичного виховання перебуває у занепаді. На різних рівнях функціонування фрізичного виховання (освітньому, профресійному) відбулися зміни, але не на краще. Фізичне виховання перестало справлятися із основним своїм завданням - фрізичною підготовкою різних груп населення, розвитком фрізичних здібностей, рухових умінь і навичок, що готує молодь до професійної діяльності і можливої військової служби [9].

Результати наукових досліджень В. О. Гружевського [10], С. Городинського та співавт. [11], І. Степанової [12] з проблеми інноваційних технологій фрізичного виховання студентів засвідчують, що вони розробляються таким чином, щоб бути оптимально розвивальними й при їх застосуванні створювалися сприятливі передумови для перебігу виховного процесу. Це пов'язано з тим, що для студентів головною метою фрізичного виховання $\epsilon$ подальше 
покращення рівня фрізичної культури, поглиблення знань про ФП, формування позитивного ставлення до систематичних занять фізичними вправами як із спортивною, так і оздоровчою спрямованістю. Теоретичні засади здоров'язберігаючих технологій, підвищення ФП та рухової активності молоді мають визначальне значення у створенні інноваційних технологій фрізичного виховання студентів. В основу створення інноваційних технологій фрізичного виховання має бути покладена національна ідея фрормування морально-досконалої особистості.

Слід зазначити, що питання вдосконалення процесу фрізичного виховання майбутніх військових лікарів розглядаються лише в одиничних роботах, що не відповідає сучасним світовим і національним тенденціям.

Мета статті. Пошуки інноваційних методів фізичного виховання для удосконалення процесу фрізичної виховання студентів фракультету підготовки лікарів для Збройних сил України.

Виклад основного матеріалу дослідження. У результаті дослідження процесів виникнення оздоровчих інновацій і розвитку фізичної культури та фрізкультурної освіти молоді А. О. Твеліна виділила ознаки інновацій у цій сфері: - циклічність розвитку; інновації у розвитку проходять однакові стадії; - зв'язок з часом відповідність інновацій сучасним вимогам суспільства; - новизна якості - революційні зміни у підходах до оздоровлення; - системність перетворення - інновації виникають на всіх рівнях організації оздоровчої діяльності [13]

Важливо, що заняття фізкультурою нового часу, повинне бути спрямоване на особистість студента, орієнтоване на його здібності, бажання і можливості. Особистісно-орієнтоване тренування - це створення умов для поліпшення фізичної підготовленості студентів, їх 
здоров'я, підвищення інтересу до занять фрізичною культурою; використання різних форм і методів організації діяльності на занятті, що дозволяють розкрити суб'єктивний досвід студента; створення атмоссрери зацікавленості кожного студента в роботі групи; використання на занятті дидактичного матеріалу, який дозволяє студенту вибирати найбільш значущі для нього види діяльності; оцінка діяльності студента не тільки за кінцевим результатом, а в ході процесу його досягнення; створення атмосфрери для природного самовираження студента.[14].

Пріоритетним напрямком модернізації структури та змісту освіти $є$ підвищення ефективності та якості викладання фрізичного виховання, яке повинно сприяти укріпленню та збереженню здоров'я студентської молоді. В. В. Мартиненко наголошує, що «фрахівець з фрізичної культури і спорту нової формації повинен знати: зміст інноваційних технологій у галузі фрізичної культури і спорту; форми, методи і принципи організації інноваційного навчання; медико-біологічні, психолого-педагогічні, соціокультурні основи інноваційних технологій у галузі фрізичної культури і спорту. Фахівець з фрізичної культури і спорту нової формації повинен уміти: планувати, організовувати і проводити заняття 3 використанням інноваційних технологій; застосовувати на заняттях сучасні засоби й методи фрізичного виховання, адекватні змісту інноваційних технологій; оцінювати ефективність використовуваних технологій і контролювати якість навчально-виховного процесу; аналізувати й коректувати свою професійну діяльність; організовувати і проводити наукові дослідження у сфері професійної діяльності» [15]

Наступним кроком модернізації навчального процесу та підвищення безпосередньої зацікавленості студентів до занять спортом потрібно розглядати метод «свободи вибору навчальноспортивної діяльності», адже традиційна організація фрізичного 
виховання не орієнтована на можливість вибору студентом виду фрізичної діяльності, що не стимулює інтересу до занять, а даний метод сприяє удосконалення особистих умінь та навичок [16].

Для досягнення максимального ефректу від занять та стимулювання зацікавленості студентів потрібно пропонувати й альтернативні види спортивно-орієнтованих занять, які перекликаються 3 сучасними тенденціями та передбачають формуванні та розвиток витривалості, сили, спритності, високого рівню працездатності. Ці навики можуть бути сформовані тільки шляхом тренування, при використанні ефекту від цілеспрямованого організованого процесу адаптації організму студента до фрізичних навантажень, необхідного обсягу й достатньої інтенсивності [17].

Прикладом таких видів спортивно-орієнтованих занять $\epsilon$ оздоровчий фітнес (health related fitness), направлений на досягнення й підтримання оптимального фрізичного стану та зниження ризику розвитку захворювань кардіореспіраторної, імунної, ендокринної й інших систем організму [18].

Оздоровчий фітнес складається з тих компонентів фрізичного фітнесу, що мають взаємозв'язок з міцним здоров'ям. Заняття оздоровчим фрітнесом направлені на досягнення та підтримання фрізичного благополуччя та зниження ризику захворювань (серцевосудинної системи, обміну речовин тощо). Поліпшення рівня занять оздоровчим фрітнесом асоційоване з нижчим ризиком захворюваності та поліпшенням якості життя [19].

Оздоровчий фрітнес складається з компонентів фрізичного фрітнесу [20]:

- кардіореспіраторної витривалість;

- склад тіла;

- сила та силова витривалість; 
- гнучкість;

Ще одним з можливих альтернативних шляхів вдосконалення і підтримки фрізичного благополуччя, який варто розглянути, є практика хатха-йоги, що заснована на активізації енергетичного потенціалу людини, профілактиці психологічного стресу і вихованні здорової гармонійної особистості [21]. Йога надає можливості, які допомагають подолати один з основних сучасних чинників погіршення здоров'я і поганого самопочуття: розбалансування системи, призначеної протистояти стресу. При правильному виконанні асан відбувається розвиток всього організму в цілому, що сприятливо відбивається не тільки на фізичному стані людини, але й на емоційному, і душевній рівновазі. У сучасному світі, 3 його стресами, 3 тим величезним потоком інфрормації, який щодня обрушується на кожного, йога сприймається як чудодійний засіб, що дарує очищення свідомості і приносить гармонію. Давня практика спокою стала для людей новим притулком. Йога сприяє виникненню більш позитивного сприйняття навколишньої дійсності, що відображається на якості життя. Методика оздоровчої гімнастики хатха-йога являється засобом покращення загального самопочуття, підвищення фізичної підготовленості і працездатності. Встановлено позитивний вплив асан на розвиток гнучкості, спритності, швидкісно-силових якостей, статичної рівноваги, а також показана можливість виконання асан не тільки роздільним способом - поширеним і загальноприйнятим в хатха-йозі, але і потоковим способом, що сприяло розвитку загальної витривалості [21].

Особливої уваги заслуговує й такий вид спорту, як бойовий гопак. Адже бойовий гопак - це система гармонійного розвитку особистості. В ньому поєднуються спорт з культурою, традиціями та світоглядом українського народу. Два основних його компоненти: основи фрізичного 
та психічного вишколу людини - реалізуються в гармонійному поєднанні, суттєво доповнюючи один одного [22].

Описано чотири напрями розвитку особистості у бойовому гопаку: оздоровчий, фрольклорно-мистецький, спортивний і бойовий [23]. Оздоровчий - ідеально підходить для гармонійного розвитку тіла, розуму і духу. Фольклорно-мистецький - орієнтований на творчі особистості, що прагнуть максимально проявити свої здібності, беручи участь у фестивалях, презентаціях та інших показових програмах в Україні та за її межами. Спортивний напрям розрахований на активних і наполегливих людей, які через утвердження бойового гопака на українських та міжнародних міжстильових змаганнях прагнуть утвердити славу українського лицарства, відродити козацьку завзятість, правдоборчий дух та лицарське благородство. Бойовий напрям окреслює шлях українського лицаря, який визначився, який намагається бути захисником Вітчизни, жертовно служить Україні та сприяє утвердженню Правди і Добра. Він гармонійно розвинув у собі три чинники сили: духу, розуму і тіла, та скеровує свою діяльність на утвердження рівності, братерства, миру і любові в ім'я процвітання нашої держави. Бойовий гопак відповідає найвищим світовим стандартам і максимально відповідає вимогам сучасності. У бойовому гопаку відпрацьована навчально-виховна система, в якій утверджено сім рівнів майстерності і чотири напрями розвитку. Перші три рівні майстерності - учнівські: «Жовтяк», «Сокіл» і «Яструб» (які відповідають III, II та I спортивним розрядам єдиної кваліфікаційної системи України); проміжний - «Джура» (відповідає кандидату в майстри спорту єдиної кваліфрікаційної системи України) та мистецькі «Козак», «Характерник» і «Волхв» (які відповідають званням майстер спорту, майстер спорту міжнародного класу та заслужений майстер спорту). «Волхв» $€$ найвищим ступенем, на якому відбувається перехід 
від власне фрізичної роботи в площину розумової боротьби, духовної та енергетичних практик [23].

Висновки: Фізичне виховання та спортивнее вдосконалення це важливий компонент базової підготовки майбутніх військових лікарів, який потребує особливої уваги зі сторони ЗВО, адже саме якісна фрізична підготовка, покликана підвищити працездатність в складних умовах діяльності, з якими можуть стикнуться військові лікарі під час виконання професійних обов'язків. Для досягнення поставлених завдань та необхідного рівня фрізичної підготовки навчальні програми слід будувати у відповідності до сучасних потреб і тенденцій часу. Використовуючи особистісно-орієнтований підхід та пропонуючи можливі додаткові компоненти навчальної дисципліни, які не $€$ класичними, проте по суті своїй сприяють досягненню необхідного рівня витривалості, сили, спритності та допоможуть підвищити рівень задоволеності студентів навчальним процесом і сприяти успішній підготовці спеціалістів.

Перевагою запропонаваних додаткових компонетів, також $є$ той фракт, що всі вони направлені на гармонізацію особистості та профрілактиці психологічного стресу.

\section{תimepamypa:}

1. Клішевич, Б. А., Гончаренко, І. Ф., Заруцький, Я. Л. (2011). Військовомедична освіта в Україні: становлення та шляхи подальшого розвитку. Науковий часопис Національного педагогічного університету імені М. П. Драгоманова. Сер. 5.: Педагогічні науки: реалії та перспективи : 3б. наук. праць. - Київ : Вид-во НПУ імені М. П. Драгоманова, 28, 8899.

2. Черних, Ю. О., Черних, О. Б. (2015). Професійні стандарти військових фрахівців: сутність, перспективи створення та використання. 
Збірник наукових праць Військового інституту Київського національного університету імені Тараса Шевченка, 49, 261-269.

3. Попадьїн, В. (2013). Мета, завдання й загальні положення програми з фрізичної підготовки військовослужбовців Військово-Морських сил Збройних сил України. Молодіжний науковий вісник Східноєвропейського національного університету імені Лесі Українки. Фізичне виховання і спорт, 9, 92-96.

4. Драчук, А., Романенко, В., Гудима, С. (2014). Порівняльна характеристика показників фрізичного стану студентів 1-4 курсів ВН3 України. Фізична культура, спорт та здоров'я нації, 18, 76-83.

5. Домашенко, А., Раєвський, Р., Канішевський, С. (2003). Становлення національної системи фрізичного виховання студентської молоді України. Педагогіка, психологія та медико-біологічні проблеми фрізичного виховання і спорту, 16, 16-23.

6. Куц, О. С., Данчук, П. С. (2008). Проблеми побудови раціональних режимів рухової активності (теоретичні аспекти проблеми). Фізичне виховання, спорт і культура здоров'я у сучасному суспільстві, 2, 165167.

7. Раєвський, Р. Т., Філінков, В. І. (2014). Профеесійно-прикладна психофрізіологічна й психофрізична підготовка студентів і фрахівців машинобудівних спеціальностей. Краматорськ.

8. Базильчук, В. Б. (2004). Організаційні засади активізації спортивнооздоровчої діяльності студентів в умовах вищого навчального закладу (автореф. дис.. канд. наук з фріз. Виховання, Львів. держ. ін-т фріз. культури, 2004) Львів, 22.

9. Круцевич, Т., Саїнчук, М., Підлетейчук, Р. (2018). Причини політики девальвації фрізичної підготовки в системі фрізичного виховання в закладах освіти України. Спортивний вісник Придніпров'я, 1, 169-174. 
10. Гружевський, В.О.(2014). Доцільність використання інноваційних технологій у формуванні особистісно-орієнтованої мотивації студентів до фрізичного виховання. Педагогіка, психологія та медико-біологічні проблеми фрізичного виховання і спорту, 3, 19-24.

11. Городинський, С., Ібрагімова, Л., Ібрагімова, С., Куліш, Н. (2014) Використання інноваційних технологій у галузі фрізичного виховання як засіб покращення організації навчального процесу. Нова педагогічна думка, 1, 108-110.

12. Степанова, І. (2014). Концепція інноваційної програми фрізичного виховання у вищих навчальних закладах. Спортивний вісник Придніпров'я, 2, 163-166.

13. Твеліна, А. О. (2014). Соціально-педагогічні передумови використання засобів оздоровчого фрітнесу в системі підготовки майбутніх вчителів фрізичної культури. Вісник Чернігівського національного педагогічного університету імені $T$ Шевченка. Сер. Педагогічні науки; фрізичне виховання та спорт, 2, 232-236.

14. Сучков, С. Л., Краснобаева, А. В. (2019). Инновационные и современные подходы к организации занятий фризической культуры в вузе. Научный аспект, 1, 861.

15. Мартиненко, В. В. (2006). Проблеми неперервної професійної підготовки фрахівців фрізичного виховання і спорту. Педагогіка, психологія та медико-біологічні проблеми фрізичного виховання $і$ спорту, 3, 55-58.

16. Темченко, В. А., Сиренко, Р. Р. (2010). Секционная фрорма организации фризического воспитания студентов. Физическое воспитание студентов, 3, 99-104.

17. Пастушкова Н. А. (2013). Розвиток фрізичної культури студентів в умовах оптимізації процесу фрізичного виховання на основі 
використання спортивно-орієнтованих технологій. Духовність особистості: методологія, теорія і практика, 2, 140-145.

18. Корносенко, О. К. (2013). Роль фрітнесу в системі оздоровчої фрізичної культури. Вісник Чернігівського національного педагогічного університету. Сер. Педагогічні науки. Фізичне виховання та спорт, 112, 228-232.

19. Беляк Ю. І. (2014). Класифрікація та методичні особливості засобів оздоровчого фрітнесу. Педагогіка, психологія та медико-біологічні проблеми фрізичного виховання і спорту, 11, 3-8.

20. Воловик, Н. (2010). Основи оздоровчого фрітнесу. Київ: Вид-во НПУ імені М. П. Драгоманова.

21. Головійчук, І. (2015). Впровадження засобів йоги в навчальний процес фрізичного виховання студентів спеціальної медичної групи. Науковий часопис Національного педагогічного університету імені М. П. Драгоманова. Сер. 15. Науково-педагогічні проблеми фрізичної культури (фрізична культура і спорт), 3(1), 110-112.

22. Шоробура І. М. (2010). Бойовий гопак як етнонаціональна система психофрізичного вдосконалення особистості . Педагогічний дискурс, 8, 244-247.

23. Богуславська, В. (2015). Еволюція науково-методичного забезпечення системи підготовки в українському національному одноборстві «Бойовий гопак». Молода спортивна наука України ( зб. наук. пр. з галузі фріз. виховання, спорту і здоров'я людини / за ред. Є. Приступи. - Львів), 19, 6-10.

\section{References:}

1. Klishevych, B. A., Honcharenko, I. F., Zarutskyi, Ya. L. (2011). Viiskovomedychna osvita $v$ Ukraini: stanovlennia ta shliakhy podalshoho rozvytku [Military medical education in Ukraine: formation and ways of further development]. Naukovyi chasopys Natsionalnoho pedahohichnoho 
universytetu imeni M. P. Drahomanova. Ser. 5.: Pedahohichni nauky: realii ta perspektyvy [Scientific journal of the National Pedagogical University named after MP Drahomanov. Ser. 5.: Pedagogical sciences: realities and prospects], no. 28, 88-99. [in Ukrainian].

2. Chernykh, Yu. O., Chernykh, O. B. (2015). Profesiini standarty viiskovykh fakhivtsiv: sutnist, perspektyvy stvorennia ta vykorystannia [Professional standards of military specialists: essence, prospects for creation and use]. Zbirnyk naukovykh prats Viiskovoho instytutu Kyivskoho natsionalnoho universytetu imeni Tarasa Shevchenka [Collection of scientific works of the Military Institute of the Kyiv National Taras Shevchenko University], no. 49, 261-269. [in Ukrainian].

3. Popadyin, V. (2013). Meta, zavdannia y zahalni polozhennia prohramy z fizychnoi pidhotovky viiskovosluzhbovtsiv Viiskovo-Morskykh syl Zbroinykh syl Ukrainy [The purpose, objectives and general provisions of the program physical training of servicemen of the Navy of the Armed Forces forces of Ukraine]. Molodizhnyi naukovyi visnyk Skhidnoievropeiskoho natsionalnoho universytetu imeni Lesi Ukrainky. Fizychne vykhovannia i sport [Youth Scientific Bulletin of Eastern Europe Lesya Ukrainka National University. Physical education and sports], no. 9, 92-96. [in Ukrainian].

4. Drachuk, A., Romanenko, V., Hudyma, S. (2014). Porivnyalna harakterstika pokaznikiv flzichnogo stanu studentiv 1-4 kurslv VNZ UkraYini [Comparative characteristics of indicators of physical condition students of 1-4 courses of Ukrainian universities]. Fizychna kultura, sport ta zdorovia natsii [Physical culture, sports and health of the nation], no. 18, 76-83. [in Ukrainian].

5. Domashenko, A., Raievskyi, R., Kanishevskyi, S. (2003). Stanovlennia natsionalnoi systemy fizychnoho vykhovannia studentskoi molodi Ukrainy [Formation of the national system of physical education of student youth of Ukraine]. Pedahohika, psykholohiia ta medyko-biolohichni problemy 
fizychnoho vykhovannia i sportu [Pedagogy, psychology and medical and biological problems physical education and sports], no. 16, 16-23. [in Ukrainian].

6. Kuts, O. S., Danchuk, P. S. (2008). Problemy pobudovy ratsionalnykh rezhymiv rukhovoi aktyvnosti (teoretychni aspekty problemy) [Problems of construction of rational modes of motor activities (theoretical aspects of the problem)]. Fizychne vykhovannia, sport $i$ kultura zdorov\&\#39;ia $u$ suchasnomu suspilstvi [Physical education, sports and health culture in modern society], no. 2, 165-167. [in Ukrainian].

7. Raievskyi, R. T., Filinkov, V. I. (2014). Profesiino-prykladna psykhofiziolohichna y psykhofizychna pidhotovka studentiv i fakhivtsiv mashynobudivnykh spetsialnostei. Profesiino-prykladna psykhofiziolohichna y psykhofizychna pidhotovka studentiv i fakhivtsiv mashynobudivnykh spetsialnostei [Professionally applied psychophysiological and psychophysical training of students and specialists in mechanical engineering specialties]. [in Ukrainian].

8. Bazylchuk, V. B. (2004). Orhanizatsiini zasady aktyvizatsii sportyvnoozdorovchoi diialnosti studentiv $v$ umovakh vyshchoho navchalnoho zakladu [Organizational principles of activating sports health activities of students in a higher education institution]. Extended abstract of candidate's thesis. Lviv: Lviv. state Inst. of Phys. Culture [in Ukrainian].

9. Krutsevych, T., Sainchuk, M., Pidleteichuk, R. (2018). Prychyny polityky devalvatsii fizychnoi pidhotovky $v$ systemi fizychnoho vykhovannia $v$ zakladakh osvity Ukrainy [The reasons for the policy of devaluation of physical training in system of physical education in educational institutions of Ukraine]. Sportyvnyi visnyk Prydniprovia [Sports Bulletin of the Dnieper], no. 1, 169-174. [in Ukrainian].

10. Hruzhevskyi, V. O. (2014). Dotsilnist vykorystannia innovatsiinykh tekhnolohii u formuvanni osobystisno-oriientovanoi motyvatsii studentiv do 
fizychnoho vykhovannia [The feasibility of using innovative technologies in the formation of personality-oriented motivation of students to physical education]. Pedahohika, psykholohiia ta medyko-biolohichni problem fizychnoho vykhovannia i sportu [Pedagogy, psychology and medical and biological problems of physical education and sports], no. 3, 19-24. [in Ukrainian].

11. Horodynskyi, S., Ibrahimova, L., Ibrahimova, S., \& Kulish, N (2014). Vykorystannia innovatsiinykh tekhnolohii u haluzi fizychnoho vykhovannia yak zasib pokrashchennia orhanizatsii navchalnoho protsesu [The use of innovative technologies in the field of physical education as a means of improving the organization of the educational process]. Nova pedahohichna dumka [New pedagogical opinion], no.1, 108-110. [in Ukrainian].

12. Stepanova, I. (2014). Kontseptsiia innovatsiinoi prohramy fizychnoho vykhovannia u vyshchykh navchalnykh zakladakh [The concept of an innovative physical education program in higher educational institutions]. Sportyvnyi visnyk Prydniprovia [Sports Bulletin of the Dnieper], no. 2, 163166. [in Ukrainian].

13. Tvelina, A. O. (2014). Sotsialno-pedahohichni peredumovy vykorystannia zasobiv ozdorovchoho fitnesu $v$ systemi pidhotovky maibutnikh vchyteliv fizychnoi kultury [Socio-pedagogical preconditions of use means of health fitness in the system of training future teachers physical culture]. Visnyk Chernihivskoho natsionalnoho pedahohichnoho universytetu imeni T Shevchenka. Ser. Pedahohichni nauky; fizychne vykhovannia ta sport [Bulletin of the Chernihiv National T. Shevchenko Pedagogical University. Ser. Pedagogical sciences; physical education and sports], no. 2, 232-236. [in Ukrainian].

14. Suchkov, S. L., Krasnobaeva, A. V. (2019). Innovatsionnyye i sovremennyye podkhody k organizatsii zanyatiy fizicheskoy kultury v vuze [Innovative and modern approaches to organization of physical education 
classes at the university]. Nauchnyy aspect [Scientific aspect], no. 1, 861. [in Russian].

15. Martynenko, V. V. (2006). Problemy neperervnoi profesiinoi pidhotovky fakhivtsiv fizychnoho vykhovannia i sportu [Problems of continuous professional training specialists in physical education and sports]. Pedahohika, psykholohiia ta medyko-biolohichni problemy fizychnoho vykhovannia i sportu.[Pedagogy, psychology and medical and biological problems of physical education and sports], no. 3,55-58. [in Ukrainian].

16. Temchenko, V. A., Syrenko, R. R. (2010). Sektsionnaya forma organizatsii fizicheskogo vospitaniya studentov [Sectional form of organization of physical educating students]. Fizicheskoye vospitaniye studentov [Physical education of students], no. 3, 99-104. [in Russian].

17. Pastushkova, N. A. (2013). Rozvytok fizychnoi kultury studentiv v umovakh optymizatsii protsesu fizychnoho vykhovannia na osnovi vykorystannia sportyvno-oriientovanykh tekhnolohii [Development of students' physical culture in minds optimization of the process of physical education on the basis of victorious sports oriented technologies]. Dukhovnist osobystosti: metodolohiia, teoriia i praktyka [Spirituality of personality: methodology, theory and practice], no. 2, 140-145. [in Ukrainian].

18. Kornosenko, O. K. (2013). Rol fitnesu v systemi ozdorovchoi fizychnoi kultury [The role of fitness in the physical health system of culture]. Visnyk Chernihivskoho natsionalnoho pedahohichnoho universytetu. Ser. Pedahohichni nauky. Fizychne vykhovannia ta sport [Bulletin of the Chernihiv National Pedagogical University. Ser. Pedagogical sciences. Physical education and sport], no. 112, 228-232. [in Ukrainian].

19. Beliak, Yu. I. (2014). Klasyfikatsiia ta metodychni osoblyvosti zasobiv ozdorovchoho fitnesu [Classification and methodological features of tools 
health fitness]. Pedahohika, psykholohiia ta medyko-biolohichni problemy fizychnoho vykhovannia i sportu [Pedagogy, psychology and medical biological problems of physical education and sports], no. 11, 3-8. [in Ukrainian].

20. Volovyk, N. (2010). Osnovy ozdorovchoho fitnesu [Basics of health fitness]. Kyiv, NPU names M. P. Drahomanov. [in Ukrainian].

21. Holoviichuk, I. (2015). Vprovadzhennia zasobiv yohy $v$ navchalnyi protses fizychnoho vykhovannia studentiv spetsialnoi medychnoi hrupy [Introduction of yoga tools in the educational process physical education of students of a special medical group]. Naukovyi chasopys Natsionalnoho pedahohichnoho universytetu imeni M. P. Drahomanova. Ser. 15. Naukovopedahohichni problemy fizychnoi kultury (fizychna kultura i sport) [Scientific journal of the National Pedagogical University names M. P. Drahomanov. Ser. 15. Scientific and pedagogical problems of physical culture (physical culture and sports)], no. 3(1), 110-112. [in Ukrainian].

22. Shorobura, I. M. (2010). Boiovyi hopak yak etnonatsionalna systema psykhofizychnoho vdoskonalennia osobystosti [Combat hopak as an ethnonational system psychophysical improvement of personality]. Pedahohichnyi Dyskurs [Pedagogical discourse], no. 8, 244-247. [in Ukrainian].

23. Bohuslavska, V. (2015). Evoliutsiia naukovo-metodychnoho zabezpechennia systemy pidhotovky $v$ ukrainskomu natsionalnomu odnoborstvi «Boiovyi hopak» [Evolution of scientific and methodological support training systems in the Ukrainian national martial arts «Combat hopak»]. Moloda sportyvna nauka Ukrainy [Young sports science of Ukraine], no. 19, 6-10. [in Ukrainian]. 
Citation: O. Moshkovskyy (2020). INNOVATIVE METHODS FOR MODERNIZATION OF PHYSICAL EDUCATION OF FUTURE MILITARY DOCTORS. New York. TK Meganom LLC. Innovative Solutions in Modern Science. 8(44). doi: 10.26886/2414-634X.7(43)2020.4

Copyright: O. Moshkovskyy ( 0 . 2020. This is an openaccess article distributed under the terms of the Creative Commons Attribution License (CC BY). The use, distribution or reproduction in other forums is permitted, provided the original author(s) or licensor are credited and that the original publication in this journal is cited, in accordance with accepted academic practice. No use, distribution or reproduction is permitted which does not comply with these terms. 